\title{
Review \\ In-ovo feeding: a review
}

Received: Oct, 2019; Accepted: Feb, 2020

\author{
Laya Kannan Silva Alves ${ }^{1 *}$, Gustavo Pereira Viana ${ }^{2}$, \\ Tamires Saboya dos Santos ${ }^{3}$, Beatriz Queiroz dos Reis ${ }^{1}$, \\ Eduarda Buck Bernardes Guimarães ${ }^{1}$, Rafael Araújo Nacimento ${ }^{1}$, \\ Camila Raineri², Cristiane Soares da Silva Araújo ${ }^{1}$
}

\begin{abstract}
The poultry industry plays a large role in the Brazilian economy. In fact, Brazil ranks as the world's leading exporter and second largest producer of poultry meat as the result of genetic improvement, animal nutrition, management, and biosecurity. During the development of bird embryos, the nutrients are stored within the egg, but carbohydrate supplementation is unsatisfactory upon hatching. Poor carbohydrate supplementation can damage the embryo development and negatively affect poultry weight. Inovo feeding is a promising technique to improve the quality of newly hatched chicks as it uses systems for feeding the embryos by inoculating nutrients into the egg amniotic fluid. However, further studies are needed in order to improve this technique and create effective implementations and protocols that can be widely used in the industry. This study aims to both review the literature on the use of in-ovo feeding and understand the perspectives of its use in the broiler production chain.
\end{abstract}

Keywords: poultry farming, broiler, Gallus gallus, embryonic nutrition.

\section{Introduction}

In 2018, the agriculture contributed with approximately 4.4 percent of the value added to the Brazilian gross domestic product (GDP), which corresponded to ca. 297.8 billion BRL (IBGE, 2019). The poultry farming industry employs over 3.6 million people (direct or indirectly) in Brazil, and accounts for around $1.5 \%$ of the national GDP. Brazil is the world's second

\footnotetext{
${ }^{1}$ Faculdade de Medicina Veterinária e Zootecnia da Universidade de São Paulo.

${ }^{2}$ Faculdade de Medicina Veterinária da Universidade Federal de Uberlândia.

${ }^{3}$ Faculdade de Zootecnia e Engenharia de Alimentos da Universidade de São Paulo.

*Corresponding author: Faculdade de Medicina Veterinária e Zootecnia da Universidade de São Paulo, Laboratório de Pesquisa em Suínos, Campus Fernando Costa, Pirassununga, SP, telefone: (19) 3565 4000, e-mail: layakannan@usp.br
} 
largest producer and leading exporter of poultry meat. The Brazilian Association of Animal Protein recorded the production of 13,056 million tons and exportation of 4,320 million tons of chicken meat in 2018 .

The success of the domestic poultry industry is a result of genetic improvement, nutrition, management techniques, health, and biosecurity (Pessoa et al., 2012). The slaughter age has been reduced by approximately $40 \%$ compared to methods used in the 1950 s. As such, $30 \%$ of the poultry life cycle corresponds to incubation, which is, therefore, the most crucial period for productive success (Gonçalves et al., 2013; Goes, 2018).

The egg structure is sufficiently complete for the proper development of a new living being. However, unlike mammals, for which nutrients are available according to the embryo requirement, birds may have their embryonic development restricted by the nutrient content in the egg (Santos, 2007). Thus, the rapid growth of poultry strains results in a higher metabolic requirement of embryos (Gonçalves et al., 2013).

Levels of carbohydrate are known to be minimal shortly after hatching. Still, considering the birds' physiological pattern, there is an inversely proportional relationship between glycogen reserves and the chick's weight (Goes, 2018). This suggests that providing nutrients during the embryo stage may improve the chick's energy and nutritional status towards the end of incubation and upon hatching (Campos et al., 2011).

Alternatives of early embryo feeding has been explored to improve embryonic development and chick performance. Egg nutrition stands out as one of such alternatives, aiming to increase the levels of nutrients available to the embryo and eventually improve its nutritional status during hatching (Campos et al., 2011; Goes, 2018).

This review aims to conceptualize and discuss the possibilities of using in-ovo feeding in the broiler production while considering the birds' physiological needs and the results of recent scientific studies on the subject. 


\section{Physiological development and embryonic nutrition}

Several physical and physiological stages of embryonic development must occur to ensure the birth of a chick on the 21st day of incubation. Embryonic growth and development are specially influenced by incubation conditions such as temperature, relative humidity, oxygenation, and hatchery management. However, good nutrition and breeding conditions play a crucial role for perfect embryonic development, as breeders are responsible for ensuring nutrient storage within the egg (Lopez et al., 1992; Gonzales, 2005). The fertile egg is macroscopically composed of three parts (shell, yolk, and albumen), which provide nutrients to the embryo (Goes, 2018). Such parts and their components are critical for healthy growth, both during embryonic development and upon hatching.

When it comes to productive efficiency, the post-hatching period is a critical period due to the higher metabolic requirement of poultry strains, since the embryonic development is restricted by the nutrients stored in the egg (Santos, 2007; Gonçalves et al., 2013). Particularly, the eggshell provides a significant portion of calcium to the developing embryo. If the diet is poor in calcium, it can negatively affect bone formation, as the availability of this mineral in the gastrointestinal tract (GIT) will be compromised (Almeida et al., 2010).

The development of the embryonic attachments (yolk sac, amnion, allantois, and chorion), which takes place during the embryological development, provides protection and nutrition to the embryo. The yolk sac not only provides nutrition but also contributes to blood cell formation and stem cell proliferation (Foye et al., 2005). Its residual is stored in the animal's abdominal cavity before hatching, constituting the only source of nutrients after birth until the provision of food in the aviary (Noy et al., 2001).

The amnion is a membrane that closely covers the embryo when it is initially formed (Lopez et al., 1992). It is made of two germ layers: the 
mesoderm, and the ectoderm. Its nutritional quality is a key factor in the birds' physiological and metabolic transition. Ammonium quantity and quality are influenced by the mother's age and nutrition, as well as by the conditions of egg incubation. Therefore, nutritional deficiencies during incubation can negatively affect the chick's development.

The chorion is the outermost fetal membrane around the embryo. The allantois stores the embryo's metabolic wastes; its size increases according to the nutritional needs of the growing embryo. The chorioallantoic membrane is formed by merging the chorion and the allantois (Foye, 2005).

Perhaps most importantly, in order to provide energy in the final third of incubation, glycogen stores are rapidly consumed in the final stage of embryonic development and during hatching (Goes, 2018). The birds' digestive tract undergoes several structural changes before hatching. The development of the gastrointestinal tract (GIT) begins within the first 96 hours of incubation. The first meal is the amniotic fluid, which is ingested prior to the eggshell's internal pipping; it is the nutritional source that will prepare the GIT for ingesting exogenous nutrients in the post-hatching stage.

The birds' gastrointestinal tract (GIT) have a rapid structural and functional development after birth. However, the chick's intestine is still physiologically immature during this period. The peak in the development of the gastrointestinal tract (GIT) occurs between the third and seventh day after hatching, upon which it slows down. Since chicks are able to digest food and assimilate nutrients only upon birth, early feeding strategies must be considered, so greater and faster growth can be achieved in early intestinal development (Muramaki et al., 1992; Lilburn, 1998; Macari and Gonzales, 2003; Bohorquez, 2010).

In-ovo feeding is considered an applicable technique to ensure the chicks' development in the final period of incubation (Uni and Ferket, 2004; 2010). The sooner the bird is fed, the greater is the initial development of the digestive tract. Consequently, better weight and performance are achieved in subsequent stages 
(Uni, 2001; Uni et al., 2005). Furthermore, amnion nutrient supplementation can accelerate the birds' intestinal development and improve their ability to digest nutrients (Uni and Ferket, 2010).

\section{In-ovo feeding}

Poultry farming is a hallmark of genetic improvement in livestock production. The development of strains for meat production has considerably decreased the recommended age for broiler slaughter. The incubation period is important for chick performance because the embryonic development is dependent on the embryo's access to nutrients that can improve its neonatal development and subsequent stages of development. These premises have led to the concept of nutrient supplementation in the pre-hatching stage, or inovo feeding (Foye et al., 2005; Pessoa et al., 2012).

In-ovo feeding is a technique whereby solutions containing nutrients that promote better embryo development are usually inoculated in the amniotic fluid. Its main objective is to provide the embryo with nutrients, cofactors, and substances that result in positive effects, such as: earlier physiological maturation of the gastrointestinal tract (GIT); improved immune response; reduced post-hatch mortality; improved nutritional status in the pre- and post-hatch stages; improved performance; and productive efficiency (Dal Pont et al., 2019).

As in-ovo feeding is a recent technique, little is known about the amounts and types of nutrients that can be used. However, its benefits have great potential throughout the broilers' productive life, including reduced production costs, since it can shorten the production period through a maximum expression of the animals' genetic potential (Uni and Ferket, 2004). For the benefits to extend to the broiler's subsequent stages, it needs access to exogenous feeding as soon as the egg hatches. 
The first studies on in-ovo feeding date back to 1982. In one of his first tests, Al-Murrani (1982) inoculated an amino acid blend into the yolk sac, which increased live weight from post-hatch to 56 days of age. Ohta et al. (2001) inoculated an amino acid blend into both the yolk sac and the inner membrane-in studying the effects of inoculations into distinct regions of the egg, they found that the inoculation of amino acids in the inner membrane had a negative impact on hatchability.

While the technique has been studied since the early 1980s, it started to garner the interest of scientists in the 2000s. Uni and Ferket (2004) conducted several studies to improve nutrition and submitted a patent application for an inoculation solution (2003 US Patent \# 6,592,878 B2 "Enhancement of development of oviparous species by in ovo feeding"). They concluded that for the embryo to be able to use the inoculated nutrients, these should be supplied in their simplest form, such as simple amino acids and sugars.

According to Uni and Ferket (2004),

- the ideal volume of inoculation varies from 0.5 to $1 \mathrm{~mL}$ depending on the nutrients that make up the solution to be inoculated, and osmolarity cannot exceed $800 \mathrm{mOsm}$,

- the ideal embryonic stage for inoculation is between days 17 and 18 of egg incubation,

- the amnion is considered to be the best place to apply the technique, as the embryo takes in amniotic fluid between the 17th and 18th days of incubation; hence, the animal naturally eats the nutrient solution before hatching.

The development of the chick in the first week after hatching is extremely important for its final performance. Studies have shown that there is a positive correlation between starting weight and final weight in broiler 
chickens: the heaviest the chick is born, the heaviest it reaches the end of the production stage (Leandro et al., 2006).

Thus, in-ovo feeding can offer significant benefits to the broilers' initial and final performance. However, the degree of response of the animals to the inoculated nutrient solution may vary according to genetic lineage, breeding age, egg size, incubation conditions, management, and inoculation processes (Uni and Ferket, 2004; Goes, 2018).

\section{Nutrients with use potential}

The nutrients to be offered to the embryo through in-ovo feeding may be related to different functions in the embryo's body. These functions include protein catabolism and anabolism, energy sources, activation of the immune system, trophism of the intestinal mucosa (Uni and Ferket, 2004).

The mucosal development depends on endogenous factors, such as the endocrine and nervous system, and exogenous factors, such as diet type and quality and quantity of ingredients (Tucci et al., 2014). As such, the trophic effects of nutrients may be related to peeling, local nutrition, and the stimulus of development by different specific nutrients.

Certain nutrients have the power to influence genetic events, assisting in the health and development of chickens. Thus, supplementation of specific nutrients in the pre-hatching stage would enable better development and better responses of the organism by favoring the expression of desirable genes (Gonçalves et al., 2009; Gonçalves et al., 2013).

The egg is considered complete in terms of nutrition. Fresh egg yolk from 50-week-old breeders contains approximately $15.62 \%$ protein, $27.32 \%$ lipid, $0.42 \%$ carbohydrate, $53.32 \%$ water, and $3.32 \%$ other nutrients (Ladgary et al., 2010). However, the percentages of amino acids, carbohydrates, vitamins, minerals and lipids are not sufficient to meet the embryo's demand in the final third of incubation and during the hatching process (Gonçalves et 
al., 2013). In addition, birds have no potential of growth retardation to compensate for a long period of poor nutrition in the neonatal stage (Abed et al., 2011). Consequently, immediate access to water and food upon hatching can assist in better development and performance.

In-ovo feeding provides access to nutrients already in the embryonic stage, avoiding any periods of deprivation and consequently underperformance. Nutrients such as beta-hydroxymethyl butyrate and amino acids such as methionine, lysine, threonine, arginine, and leucine can be used to assist in metabolic functions (Uni and Ferket, 2004), while nutrients such as sucrose, dextrin, maltose, and glucose can be inoculated to supply energy to the embryo. If the goal is to stimulate the embryo's immune system, solutions with vitamin E, copper, and probiotics can be used in addition to substances such as glutamine, zinc, and butyric acid. These nutrients have already been proven effective in scientific studies (Tako et al., 2004; Kornasio et al., 2011; Dal Pont et al., 2019).

Campos et al. (2011) inoculated saline solution, carbohydrate nutrient solution (glucose + sucrose), 12 vitamins, and chelated minerals (zinc, manganese, and copper) into embryos on the 17.5 day of incubation to assess the effect on the broilers' performance and immunological development. Table 1 shows that inoculating $2.5 \%$ glucose $+3 \%$ sucrose solution led to the best hatchability and best performance at the age of 21 days.

Table 1 Effect of inoculating nutrient solutions on hatchability, weight gain (WG), feed conversion ratio (FCR), and broiler yield at the age of 21 days. 
Table 1 Effect of inoculation of in egg nutrient solutions on hatchability, weight gain (WG), feed conversion (CA) and broiler yield of broilers at 21 days of age.

\begin{tabular}{|c|c|c|c|c|c|}
\hline \multirow[t]{2}{*}{ Treatment } & \multirow{2}{*}{$\begin{array}{l}\text { Hatchability } \\
(\%)\end{array}$} & \multirow[t]{2}{*}{ Weight gain } & \multirow{2}{*}{$\begin{array}{c}\text { Feed } \\
\text { conversion }\end{array}$} & \multicolumn{2}{|c|}{ Broiler yield } \\
\hline & & & & $\begin{array}{c}\text { Bone-in } \\
\text { breast (\%) }\end{array}$ & $\begin{array}{c}\text { Breast } \\
\text { fillet (\%) }\end{array}$ \\
\hline Control & $93.57 \mathrm{a}$ & $673.54 \mathrm{~b}$ & $1.53 \mathrm{a}$ & $19.37 \mathrm{~b}$ & $15.22 \mathrm{~b}$ \\
\hline $\begin{array}{l}\text { Saline solution } \\
\qquad(0.5 \%)\end{array}$ & $84.64 \mathrm{ab}$ & $682.60 \mathrm{ab}$ & $1.54 \mathrm{a}$ & $19.32 \mathrm{~b}$ & $15.10 \mathrm{~b}$ \\
\hline $\begin{array}{c}\text { Glucose }(2.0 \%)+ \\
\text { sucrose }(2.0 \%)\end{array}$ & $82.50 \mathrm{~b}$ & $690.51 \mathrm{ab}$ & $1.46 \mathrm{ab}$ & $19.34 \mathrm{~b}$ & $15.15 b$ \\
\hline \multicolumn{6}{|l|}{$\begin{array}{c}\text { Glucose }(2.5 \%)+ \\
\text { sucrose }(3.0 \%)\end{array}$} \\
\hline Vitamin solution ${ }^{1}$ & $87.50 \mathrm{ab}$ & $691.90 \mathrm{ab}$ & $1.49 \mathrm{a}$ & $19.43 \mathrm{~b}$ & $15.30 \mathrm{~b}$ \\
\hline Mineral solution ${ }^{2}$ & $83.21 \mathrm{~b}$ & $690.27 \mathrm{ab}$ & $1.50 \mathrm{a}$ & $19.29 \mathrm{~b}$ & $15.20 \mathrm{~b}$ \\
\hline Average & 86.61 & 688.62 & 1.49 & 19.42 & 15.26 \\
\hline $\begin{array}{l}\text { Coefficient of } \\
\text { variation (\%) }\end{array}$ & 5.4 & 3.2 & 5.9 & 2.3 & 2.7 \\
\hline
\end{tabular}

${ }^{1} 3.9 \mathrm{~g}$ of vitamin $\mathrm{E} / \mathrm{L}, 516 \mathrm{mg}$ of vitamin $\mathrm{A} / \mathrm{L}, 1.2 \mathrm{mg}(571428 \mathrm{UI})$ of vitamin $\mathrm{D}_{3} / \mathrm{L}, 120 \mathrm{mg}$ of folic acid/L, $2.0 \mathrm{~g}$ of calcium pantothenate $/ \mathrm{L}, 480 \mathrm{mg}$ of vitamin $\mathrm{B}_{6} / \mathrm{L}, 258 \mathrm{mg}$ of vitamin $\mathrm{B}_{1} / \mathrm{L}$, $228 \mathrm{mg}$ of vitamin $\mathrm{K}_{3} / \mathrm{L}, 852 \mathrm{mg}$ of vitamin $\mathrm{B}_{2} / \mathrm{L}, 12 \mathrm{mg}$ of Biotin $/ \mathrm{L}, 3 \mathrm{mg}$ of vitamin $\mathrm{B}_{12} / \mathrm{L}$, $3000 \mathrm{mg}$ de Niacin/L in saline solution $0.5 \%$.

${ }^{2} 0.05 \mathrm{~g}$ zinc-methionine/L, $0.05 \mathrm{~g}$ manganese-methionine/L e $0.05 \mathrm{~g}$ copper-methionine/L in saline solution $0.5 \%$.

Averages followed by different letters on the line are statistically different from each other according to the SNK test at 5\% probability. Adapted from Campos et al. (2011).

According to Tako et al. (2004), in-ovo inoculation of sugars improves bird performance as it increases the energy available to the embryo, leading to increased glycogen stores and consequently decreasing the use of muscle proteins. Furthermore, digestive and absorptive capacity is reduced in the final embryonic stage, so the inoculation of carbohydrates can be positive, 
since they can increase enzymatic activities in the intestine, improving the embryo's digestion and absorption capacity.

As in-ovo feeding is a recent technique, there is a wide range of nutrients that require further studies and research. Either alone or in combination, they can potentially make up feasible solutions that may be developed for use at the industrial level. Such solutions are supposed to contribute to the performance in the post-hatching stages while not impairing the embryonic development (Gonçalves et al., 2013; Goes, 2018).

\section{Efficiency-related parameters of the method}

A factor that may help in disseminating in-ovo inoculation is the practice of in-ovo vaccination, which is widespread in commercial hatcheries. The same technique can be used to provide the embryo with a nutrient solution (Uni and Ferket, 2004).

Inoculating nutrient solutions in fertile eggs is believed to allow the embryo to absorb nutrients before birth and thus stimulate its development. Thus, such technology can prepare the bird for the challenges of the first hours upon hatching by promoting higher nutritional status (Uni and Ferket, 2003). However, some authors have not obtained good hatchability and chick performance 10 days after they had inoculated linoleic acid, glutamine and glucose in eggs of heavy broilers on the 16th day of incubation (Pedroso et al., 2006).

Such findings may be the result of possible inadequacies in the method or even in inoculated solutions as Uni et al. (2005) indicated that inoculating carbohydrates or proteins into embryos on the 18th day of incubation increased their energy reserve levels. They also observed a higher pre-hatch and 10-day-old live weight when using $250 \mathrm{mg}$ of carbohydrates in ovo, a finding that can be ascribed to the hepatic glycogen reserve obtained by inoculating the nutrient solution. 
When it comes to the energy levels, the inoculation of low glucose levels has not been efficient in improving performance, nor has it showed reduced embryonic mortality rate. Therefore, low glucose levels do not contribute as an energy supplement to the embryonic development (Ipek et al., 2004).

As for the site of inoculation, nutrient inoculation through the tube technique causes a higher embryonic mortality rate when compared to direct application to the allantoic cavity. In addition, enteric modulation nutrients should be inoculated directly into the allantoic cavity, enabling the embryo to ingest the solution, which will be available with the amniotic fluid (Uni and Ferket, 2003; Leitão et al., 2010).

With regard to hatchability, consideration should be given to the interval between laying and incubation to obtain good air chamber formation and embryo performance. Consequently, it is key that the management of farms and hatcheries is performed correctly to ensure positive performance results (Jaranukki et al., 2005). Uni et al. (2005) emphasize that the in-vivo inoculation technique has the potential to improve zootechnical performance indexes in healthy and good quality animals.

\section{Conclusions}

In-ovo feeding is a feasible alternative to improve poultry production efficiency and has a high potential for innovation and commercialization in the poultry industry. The practice is still considered recent and a potential project for the near future. Further research is necessary to improve the technique, define an ideal embryo-friendly solution, and establish a protocol for implementation. Questions such as the efficiency of the method, the response to its application in challenging situations, and the benefits in the production indexes need to be clarified through scientific studies oriented to animal nutrition. 


\title{
Alimentação in ovo: uma revisão
}

\begin{abstract}
Resumo
A avicultura tem tido papel expressivo na economia brasileira, estando o país classificado como o segundo maior produtor e o maior exportador do mundo. Esse resultado é proveniente de avanços no melhoramento genético, nutrição, manejo e biosseguridade. Nas aves, os nutrientes utilizados durante o desenvolvimento embrionário estão contidos no ovo, sendo escassa a reserva de carboidratos logo após a eclosão do pintainho. Essa restrição pode causar prejuízos ao desenvolvimento embrionário, impactando negativamente no peso das aves. Diante disso, a nutrição in ovo mostra-se como uma técnica promissora, que visa prover nutrientes ao embrião por meio da inoculação de soluções com efeitos benéficos ao seu desenvolvimento. Contudo, são necessários mais estudos no intuito de aprimorar a técnica e criação de protocolos efetivos que possam ser amplamente utilizados pela indústria. Nesse contexto, o objetivo desta revisão de literatura foi abordar e depreender as perspectivas da utilização da técnica nutrição in ovo na cadeia produtiva de frangos de corte.

Palavras-chave: Avicultura, Frangos de corte, Gallus gallus, Nutrição embrionária.
\end{abstract}

$* * *$

\section{References}

ABPA. Relatório anual 2018. 18th ed. Brasília, DF, 176p, 2018. Available at: http://abpa-br.com.br/storage/files/relatorio-anual-2018.pdf. Access on: 10 Oct. 19.

ABED, F.; KARIMI, A.; SADEGHI, G.; SHIVAZAD, M.; DASHTI, S.; SADEGHI-SEFIDMAZGI, A. Do broiler chicks possess enough growth potential to compensate long-term feed and water depravation during the neonatal period? South Afr J Anim Sci, Pretoria, 41: 33-39, 2011. https://doi.org/10.4314/sajas.v41i1.66037

ALMEIDA PAZ, I.C.L.; MENDES, A.A.; BALOG, A.; MARTINS, M.R.F.B.; ALMEIDA, I.C.L.; FERNANDES, B.C.S.; MILBRADT, E.L.; VULCANO, L.C.; KOMIYAMA, C.M.; CARDOSO, K.F.G. Níveis de cálcio e avaliação óssea e de 
ovos de avestruzes reprodutoras. Arch Zootec, Córdoba, 59: 459-462, 2010. https://doi.org/10.21071/az.v59i227.4723

AL-MURRANI, W.K. Effect of injecting amino acids into the egg on embryonic and subsequent growth in the domestic fowl. Br Poult Sci, Londres, 23: 171174, 1982. https://doi.org/10.1080/00071688208447943

BOHORQUEZ, D.V. Nutritional influences on the ultra-structural development of the small intestinal epithelium of the perinatal turkey embryo and poult. Ph.D. Dissertation, North Carolina State University, Raleigh, NC, 2010.

CAMPOS, A.M.A.; ROSTAGNO, H.S.; GOMES, P.C.; SILVA, E.A.; ALBINO, L.F.T.; NOGUEIRA, E.T. Efeito da inoculação de soluções nutritivas in ovo sobre a eclodibilidade e o desempenho de frangos de corte. Revista Brasileira de Zootecnia, Viçosa, v.40, n.8, 2011. Available at: http://www.scielo.br/scielo.php?script=sci_arttext\&pid=S151635982011000800013. Access on: 18 Oct. 19. https://doi.org/10.1590/S1516$\underline{35982011000800013}$

DAL PONT, G.C.; GOES, E.C.; SILVA, K.F.; OLIVEIRA, S.G.; ROCHA, C.; MIORKA, A. Glyecerol in ovo feeding as na energy substrate improves performance of broilers from Young breeders. Journal of Animal Physiology and Animal Nutrition, Berlim, v. 103, n. 5, p. 1453-1461, 2019. https://doi.org/10.1111/jpn.13153

FOYE, O.; FERKET, P.; UNI, Z. The effects of in ovo feeding of arginine and/or betahydroxy beta-metylbutyrate (HMB) on glycogen metabolism and growth in turkey poults, Poultry Science, Champaign, 84: (Supplement 1), 2005. 
GOES, E.C. Putrescina como um componente na nutrição in ovo de frangos de corte. Dissertação (Mestrado). Universidade Federal do Paraná, 2018.

GONÇALVES, F.M.; SANTOS, V.L.; CONTREIRA, C.L.; FARINA, G.; KREUZ, B.S.; GENTILINI, F.P.; ANCIUTTI, M.A.; RUTZ, F. Nutrição in ovo: estratégia para nutrição de precisão em sistemas de produção avícola. Revista Archivos de Zootecnia, Córdoba, v. 62, n. 237, p. 54-55, 2013.

GONÇALVES, F.M.; CORRÊA, M.N.; ANCIUTI, M.A.; GENTILINI, F.P.; ZANUSSO, J.T.; RUTZ, F. Nutrigenômica: situação e perspectivas na alimentação animal. Rev Port Ciênc Vet, Lisboa, 104: 569-572, 2009.

GONZALES, E. Análise de problemas de eclodibilidade e fertilidade de plantéis avícolas por métodos de embriodiagnóstico. Em: X Congresso Nacional de Zootecnia Zootec. Anais eletrônicos [online]. Campo Grande, 2005. Available at: http://www.abz.org.br/files.php?file=documentos/Elisabeth_910013612. Access on: 05 Oct. 19.

IBGE, 2019. PIB cresce 1,1\% em 2018 e fecha ano em $\mathrm{R} \$ 6,8$ trilhões. Available at: https://agenciadenoticias.ibge.gov.br/agencia-sala-deimprensa/2013-agencia-denoticias/releases/23886-pib-cresce-1-1-em-2018-efecha-ano-em-r-6-8-trilhoes. Access on: 10 Oct. 19.

IPEK, A.; SAHAN, U.; YILMA, B. The effects of in ovo ascorbic acid and glucose injection in broiler breeder eggs on hatchability and chick weight. Arch für Geflügelk, 68: 132-135, 2004. 
JARANUKKI, R.I.; HERNÁNDEZ, Z.J.S.; SIERRA, V.A.C.; VARGAS, L.S. Relaciones entre características del huevo incubable y nacimiento de pollitos. Arch Zootec, Córdoba 54: 437-441, 2005.

KORNASIO R, HALEVY O, KEDAR O, UNI Z. Effect of in ovo feeding and its interaction with timing of first feed on glycogen reserves, muscle growth, and body weight. Poultry Science, Champaign, 90:1467-1477, 2011. https://doi.org/10.3382/ps.2010-01080

LADGARY, L.; CAHANER, A.; KEDAR, O.; UNI, Z. Yolk sac nutrient composition and fat uptake in late-term embryos in eggs from young and old broiler breeder hens. Poultry Science, Champaign, v.89, n.11, p.2441-2452, 2010. https://doi.org/10.3382/ps.2010-00681

LEANDRO, NSM, CUNHA, WCP, STRINGHINI, JH, CRUZ, CP, CAFÉ, MB, MATOS, MS. Influência do peso inicial de pintos de corte sobre o desempenho e o rendimento de carcaça e a viabilidade econômica da produção. Revista Brasileira de Zootecnia, Viçosa, 35(6):2314-2321, 2006. https://doi.org/10.1590/S1516-35982006000800017

LEITÃO, A.R.; LEANDRO, M.N.; STRINGHINI, H.J.; CAFÉ, M.B. e ANDRADE, M.A. Inoculação de maltose, sacarose ou glicose em ovos embrionados de baixo peso. Acta Scient Animal Sci, Maringá, 32: 93-100, 2010. https://doi.org/10.4025/actascianimsci.v32i1.5910

LILBURN, M.S. Practical aspects of early nutrition in poultry. Journal Applies Poultry Research, Atenas, 7: 420-424, 1998. https://doi.org/10.1093/japr/7.4.420

LOPEZ TORRE, B.; TOVAR, J.; URIARTE, S.; ALDAZABAL, P. The nutrition of the fetus with intestinal atresia: studies in the chick embryo 
model. Journal of Pediatric Surgery, Filadélfia, v. 27, n. 10, p. 1325-1328, 1992. https://doi.org/10.1016/0022-3468(92)90288-I

MACARI, M.; GONZALES, E. Manejo da incubação. Fundação Apinco de Ciência e Tecnologia Avícolas. FACTA, Jaboticabal, 537 pp, 2003.

MURAKAMI, H.; AKIBA, Y.; HORIGGUCHI, M. Growth and utilization of nutrients in newlyhatched chicks with or without removal of residual yolk. Growth Dev Aging, Lakeland, 56: 75-84, 1992.

NOY, Y.; SKLAN, D. Yolk and exogenous feed utilization in the post-hatch chick. Poultry Science, Champaign, v.80, p. 1490-1495, 2001. https://doi.org/10.1093/ps/80.10.1490

OHTA, Y.; KIDD, M.T.; ISHIBASHI, T. Embryo growth and amino acid concentration profiles of broiler breeder eggs, embryos, and chicks after in ovo administration of amino acids. Poultry Science, Champaign, v.80, p. 14301436, 2001. https://doi.org/10.1093/ps/80.10.1430

PEDROSO, A.A.; CHAVES, L.S; LOPES, K.L.A.M.; LEANDRO, N.S.M.; CAFÉ, M.B.; STRINGHINI, J.H. Inoculação de nutrientes em ovos de matrizes pesadas. Revista Brasileira de Zootecnia, Viçosa, v. 35, n.5, 2006. http://dx.doi.org/10.1590/S1516-35982006000700020

PESSOA, G.B.S.; TAVERNARI, F.C.; VIEIRA, R.A.; ALBINO, L.F.T. Novos conceitos em nutrição de aves. Revista Brasileira de Saúde e Produção Animal, Salvador, v. 13, n.3, 2012. https://doi.org/10.1590/S1519-99402012000300015

SANTOS, T.T. Influência da inoculação de ingredientes intra ovo em aspectos produtivos e morfológicos de frangos de corte oriundos de distintos pesos de 
ovos. Dissertação (Mestrado). Faculdade de Zootecnia e Engenharia de Alimentos da Universidade de São Paulo. 63 pp, 2007.

TAKO, E.; FERKET, P.R.; UNI, Z. Effects of in ovo feeding of carbohydrates and betahydroxy-betamethylbutyrate on the development of chicken intestine. Poultry Science, Champaign, v.83, p.2023-2028, 2004. https://doi.org/10.1093/ps/83.12.2023

TUCCI, F.M.; THOMAZ, M.C.; HANNAS, M.I.; SCANDOLERA, A.J.; BUNDINO, F.E.L. Efeitos da adição de agentes tróficos na dieta de leitões desmamados sobre a expressão da enzima ornitina descarboxilase, os conteúdos de proteína e DNA e o desempenho. Revista Ciência Animal Brasileira, Goiânia, V. 15, 2014. Available at: http://www.scielo.br/pdf/cab/v15n4/a01v15n4.pdf. Access on: 18 Oct. 19 https://doi.org/10.1590/1089-6891v15i412587

UNI, Z. Bases fisiológicas e molecular gastrintestinal durante o período pré e pós eclosão, 2001. In: CONFERÊNCIA APINCO DE CIÊNCIA E TECNOLOGIA AVÍCOLA. Anais... Campinas, SP. pp: 109-116. Uni, Z. e Ferket, P.R. 2003. Enhancement of development of oviparous species by in ovo feeding. US Patent $\mathrm{n}^{\circ} \quad 6592878$. http://patentscope.wipo.int/search/en/WO2002012436 (30 Jul. 2012).

UNI, Z.; FERKET, P.R. 2003. Enhancement of development of oviparous species by in ovo feeding. US Patent $\mathrm{n}^{\mathrm{o}}$ 6592878, 15 jul. 2003. http://patentscope.wipo.int/search/en/WO2002012436 (30 Jul. 2012)

UNI, Z.; FERKET, P.R. Methods for early nutrition and their potential. World's Poultry Sci J, Ithaca, 60: 101-111, 2004. https://doi.org/10.1079/WPS20049 
UNI, Z.; FERKET, P.R. Alimentação in ovo. Impacto sobre o desenvolvimento intestinal, teor corporal de energia e desempenho. In: CONFERÊNCIA FACTA 2010 DE CIÊNCIA E TECNOLOGIA AVÍCOLAS. Anais... Santos, SP. pp. 109-122v, 2010.

UNI, Z.; FERKET, P.R; TAKO, E.; KEDAR, O. In ovo feeding improves energy status of lateterm chicken embryos. Poultry Sci, Champaign, 84: 764-770, 2005. https://doi.org/10.1093/ps/84.5.764 